\title{
Gonad maturation of Haemulon plumieri (Teleostei: Haemulidae) in Ceará state, Northeastern Brazil
}

\author{
Shinozaki-Mendes, RA. ${ }^{a *}$, Santander-Neto, J. ${ }^{b}$,Silva, JRF. ${ }^{c}$ and Hazin, FHV. ${ }^{b}$ \\ ${ }^{a}$ Unidade Acadêmica de Serra Talhada, Laboratório de Biologia Pesqueira, Universidade Federal Rural de \\ Pernambuco - UFRPE, Fazenda Saco, s/n, CP 063, CEP 56900-000, Serra Talhada, PE, Brazil \\ 'Laboratório de Oceanografia Pesqueira, Departamento de Pesca e Aquicultura, Universidade Federal Rural de \\ Pernambuco - UFRPE, Av. Dom Manuel de Medeiros, s/n, Dois Irmãos, CEP 52171-900, Recife, PE, Brazil \\ ${ }^{c}$ Laboratório de Histologia, Departamento de Biologia, Universidade Federal do Ceará - UFC, Av. Mister Hull, s/n, \\ Bloco 909, Pici, CEP 60455-760, Fortaleza, CE, Brazil \\ *e-mail: renataasm@gmail.com
}

Received March 6, 2013 - Accepted July 10, 2012 - Distributed May 31, 2013

(With 4 figures)

\begin{abstract}
To elucidate the reproductive cycle of any animal, it is first necessary to understand the development of the germ cells and how this process occurs throughout the reproductive tract. Thus, the aim of the present study was to understand the oogenesis and spermatogenesis, as well as the ovarian and testis maturation and type of spawning, of Haemulon plumieri. A total of 119 females and 136 males were analysed. Based on micro and macroscopic characteristics of gonads, the following stages of maturation for females were determined: immature, maturing, ripe, partially spawning, spawning and resting. For males, only the stages immature, maturing, ripe and spent were observed. We can conclude that the ovarian development occurs cyclically, in which the female can spawn more than two times during the reproductive season with the spawning "synchronous in more than two groups". Since males do not present the "rest" stage after copulation, the maturation process is continuous.
\end{abstract}

Keywords: maturation, reproduction, oogenesis, spermatogenesis.

\section{Maturação gonadal de Haemulon plumieri (Teleostei: Haemulidae) no Nordeste do Brasil}

\begin{abstract}
Resumo
Para se conhecer a biologia reprodutiva de qualquer animal, é fundamental o conhecimento prévio do desenvolvimento das células germinativas e como esse processo ocorre ao longo do trato reprodutivo. Desta forma, o objetivo do presente trabalho foi descrever a oogênese e a espermatogênese, bem como o desenvolvimento maturacional dos ovários e testículos, e o tipo de desova do Haemulon plumieri. Foram analisadas 119 fêmeas e 136 machos. A partir das características macro e microscópicas das gônadas, foram estabelecidos os seguintes estágios de maturação para fêmeas: imatura, em maturação, matura, parcialmente desovada, desovada e em repouso. Para os machos, foram identificados apenas os seguintes estágios: imaturo, em maturação, maturo e esvaziado. A partir das análises, pôde-se concluir que o desenvolvimento ovariano é cíclico, em que a fêmea pode desovar mais de duas vezes por estação, por apresentar a desova do tipo 'sincrônica em mais de dois grupos'. Uma vez que os machos não apresentam o estágio 'em repouso' após a cópula, o processo de maturação é contínuo.
\end{abstract}

Palavras-chave: maturação, reprodução, oogênese, espermatogênese.

\section{Introduction}

The Haemulon plumieri (Lacépede, 1801), popularly known as white grunt, is a typical reef-associated and tropical species found in warm and temperate waters of the Western Atlantic, from Bermudas and Maryland, USA, to Santa Catarina, in southern of Brazil (GarciaJúnior et al., 2010).

To elucidate the reproductive cycle of any animal, it is first necessary to understand the development of the germ cells and how this process occurs throughout the reproductive tract. The importance of studies that combine microscopic to macroscopic characteristics is justified by the need to ensure a correct classification of stages of development, not mixing juveniles with adults in "rest" stage, an error commonly observed in studies merely based on macroscopic analysis.

Only two studies concerning gonad development of H. plumieri was observed. Alves and Aragão (1973) described the maturation of the species in northeastern Brazil and 
Palazón-Fernandes (2007) studied its reproductive biology in Venezuela. However, Alves and Aragão (1973) had used obsolete techniques due to the time at which they had conducted their research. Thus, there are many gaps to be filled and further studies to be made since there is a lack of information regarding the process of gonad maturation and type of spawning.

The aim of the present study was to understand the oogenesis and spermatogenesis, as well as the ovarian and testis maturation and type of spawning, of $H$. plumieri, through macroscopic and microscopic descriptions of the reproductive system.

\section{Material and Methods}

Specimens of $H$. plumieri were monthly collected between January 2006 and August 2007, off the state of Ceará, at distances from the shore ranging from 5 to 45 miles $\left(03^{\circ} 00^{\prime} \mathrm{S}\right.$ to $03^{\circ} 45^{\prime} \mathrm{S} 038^{\circ} 05^{\prime} \mathrm{W}$ to $039^{\circ} 00^{\prime} \mathrm{W}$ ) using line and baited hook. 255 specimens of $H$. plumieri were analysed; 119 were females and 136 males.

Animals were initially immobilised by thermal shock at $-5{ }^{\circ} \mathrm{C}$ and measured to obtain the fork length $\left(\mathrm{L}_{\mathrm{F}}\right)$ and total weight $\left(\mathrm{W}_{\mathrm{T}}\right)$. They were dissected for the collection of the reproductive tract. The gonads were measured in length $\left(\mathrm{L}_{\mathrm{G}}\right)$ and width $\left(\mathrm{S}_{\mathrm{G}}\right.$, on the middle region), with precision of $0.01 \mathrm{~cm}$ and weight $\left(\mathrm{W}_{\mathrm{G}}\right)$ with precision of $0.01 \mathrm{~g}$.

The reproductive tract of each specimen was observed and photographed. Then, sections from the anterior, middle and posterior regions of the gonads from 10 specimens $(5$ males and 5 females) were selected to investigate possible differences in maturation between portions of the gonad. For all other specimens $(n=245)$ the middle section of the gonad was collected. These fragments were placed in a $4 \%$ formaldehyde solution for 24 hours and then stored in a $70 \%$ ethanol solution. They were dehydrated in an ethanol series of increasing concentration, followed by diaphanisation in xylene and impregnation and embedding in paraffin at $60^{\circ} \mathrm{C}$. The blocks of paraffin wax were then cut into $5 \mu \mathrm{m}$ sections and stained with Hematoxylin-Eosin for detection of acid and basic substances; Alcian Blue/ Periodic Acid Schiff, for the detection of glycoproteins, mucopolysaccharide acids and glycogen; and Gomori's Trichrome for the differentiation of tissues (adapted from Junqueira and Junqueira, 1983; Tolosa et al., 2003). Three microscope slides were made for each paraffin block. The identification of sex was made after microscopic examination of the gonads, based on the germ cells observed.

In order to characterise and classify cell development stage, cells were measured in maximum diameter and nuclei, with only those that showed the nuclei in the section observed being used for that purpose. Besides the relation nucleus/cytoplasm, it was also observed the reaction to the dyes, the nature of the cytoplasm contents (for females), and the presence of acrosome (for males).

Descriptive statistics was used for the calculation of the mean and standard derivation for the diameters of cell $\left(\mathrm{D}_{\mathrm{C}}\right)$ and nucleus $\left(\mathrm{D}_{\mathrm{N}}\right)(n=30$, for each stage of development), as well as for length, width and weight of gonads $(n=255)$ at each maturation stage.
The gonad measurements (length, width and weight) were tested for normality (Shapiro-Wilk test) and homoscedasticity (Bartlett test). Since the data were not normally distributed and were not homoscedastic ( $p<0.02$ for all analyses), the Kruskal-Wallis test (Mendes, 1999) was used; the median values were ranked and the maximum difference between treatments were analyzed, based on the standard error (Zar, 1984), to determine the statistical significance of differences among means.

In order to define the type of spawning, the diameters of all oocytes present in cross sections of the ovary in different maturity stages were measured. The type of spawning was defined, according to Marza (1938), as synchronous in one group, synchronous in two groups, synchronous in more than two groups, or asynchronous.

\section{Results}

\subsection{Reproductive system description}

The reproductive system consisted in a pair of gonads that have a commissure in the terminal portion near the urogenital orifice. They varied in size and colour, according to the degree of development of the germ cells, and the structures forming the gonads. In some specimens, it was not possible to differentiate between sexes macroscopically due to the reduced gonadal size.

The ovaries presented a fusiform shape, with colour ranging from translucent, with barely noticeable vascularisation in the least developed stage, to orange with a large vasculature, easily noticeable, in the most developed stage. Ovary length varied between 2.05 and $7.10 \mathrm{~cm}$, width from 0.22 to $1.95 \mathrm{~cm}$ and weight between 0.10 and $12.79 \mathrm{~g}$, occupying from $0.51 \%$ to $44.72 \%$ of the abdominal cavity, depending on the degree of development.

Testicles, when undeveloped, were thin and translucent. When more developed, they had a lateral flattening and a smooth texture, acquiring a whitish colour. Testes length varied between 0.90 and $7.70 \mathrm{~cm}$, width of 0.15 to $1.60 \mathrm{~cm}$, and weight between 0.01 and $2.25 \mathrm{~g}$, occupying from $0.20 \%$ to $15.40 \%$ of the abdominal cavity.

Female germ cells were classified as oogonia, previtellogenic oocytes (early and final stages), cytoplasmic vesicle oocytes (early, middle and final stages), vitellogenic oocytes, mature oocytes, hydrated oocytes, and atretic oocytes, as follows:

Oogonia (Oo) (Figure 1a): the smallest germ line cells, having $13.15 \pm 1.03 \mu \mathrm{m}$ in diameter. They have a quite developed nucleus $(8.05 \pm 0.87 \mu \mathrm{m})$, with scanty cytoplasm, of a basophilic character, and little protein. The cytoplasm is, on average, $71.8 \%$ of the cell (nucleus/ cell ratio).

Pre-vitellogenic oocytes. Early stage (Po1) (Figure 1b, white arrow): cytoplasm begins to develop and reveals strong basophilia. In the nucleus, chromatin is nuclear. Diameters of cell and nucleus are $36.96 \pm 2.48 \mu \mathrm{m}$ and $10.46 \pm 0.81 \mu \mathrm{m}$, respectively. Final stage (Po2) (Figure 1b, black arrow): cytoplasm remains basophilic. In the nucleus, nucleoli are positioned on the periphery being thus called perinuclear. The diameter of cell and nucleus are $38.16 \pm 1.56 \mu \mathrm{m}$ and $15.97 \pm 0.03 \mu \mathrm{m}$, respectively. 

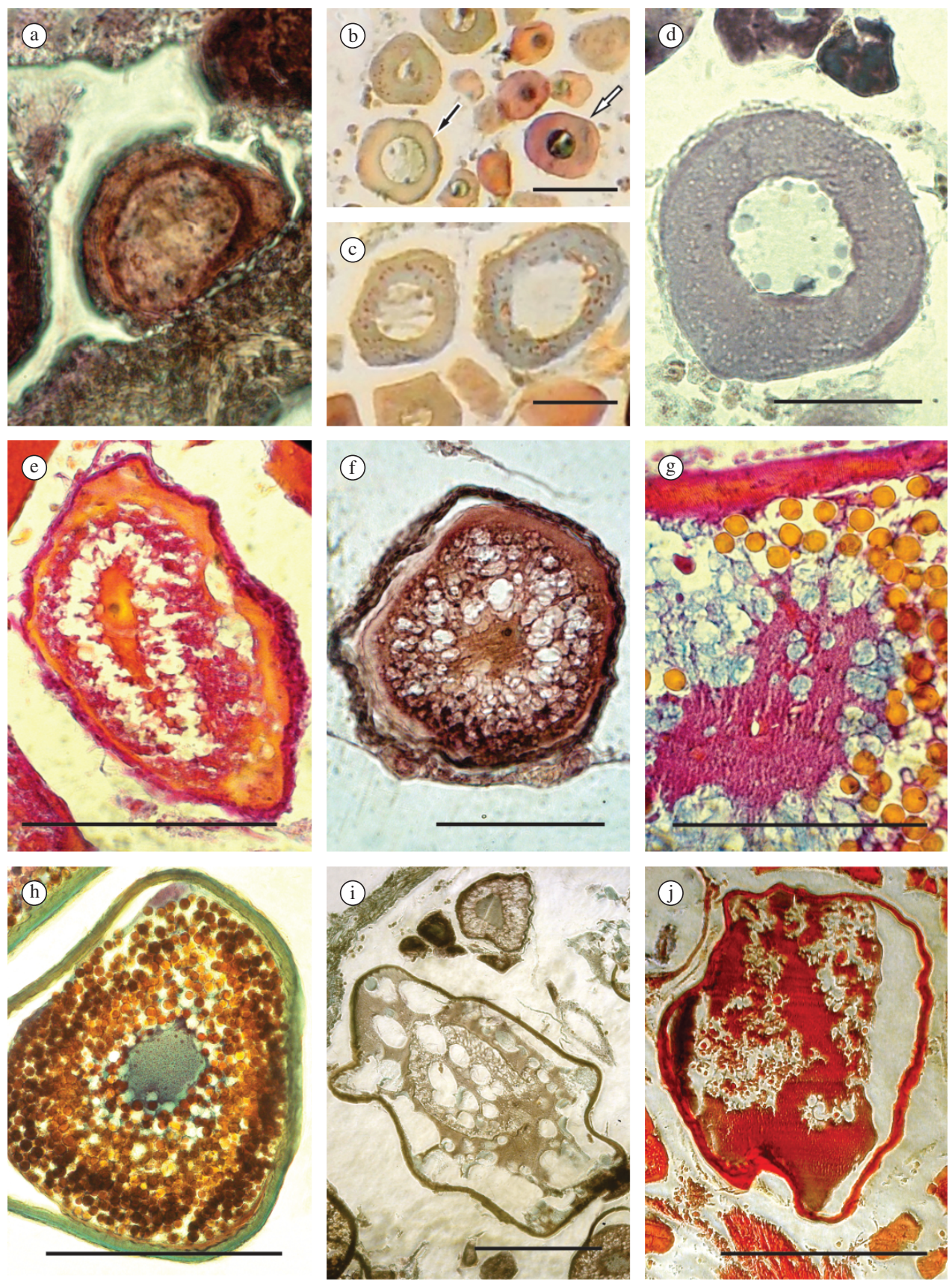

Figure 1. Photomicrographs of female germ cells of H. plumieri. a) oogonia; b) pre-vitellogenic oocyte with nuclear chromatin (white arrow) and pre-vitellogenic oocyte with perinuclear chromatin (black arrow); c) very initial cytoplasmic vesicle oocytes; d) Detail of the initial cytoplasmic vesicle oocytes; e) cytoplasmic vesicle oocytes; f) final cytoplasmic vesicle oocytes; g) vitellogenic oocyte; h) mature oocyte; i) hydrated oocyte; j) atretic oocyte. Staining: Gomori's Trichrome (a, b, c, d, f, h, i) and Alcian Blue/PAS (e, g, j). Scale Bar: $10 \mu \mathrm{m}$ (a), $25 \mu \mathrm{m}$ (b, c, d), $50 \mu \mathrm{m}$ (e), $100 \mu \mathrm{m}$ (f, g), and $250 \mu \mathrm{m}$ $(h, i, j)$.

Cytoplasmic vesicle oocytes. Early stage (Cv1) (Figures 1c, d): quite similar to Po2, but small cytoplasmic vesicles were observed, which start to become acidophilic and more proteic. The chromatin remains perinuclear. The diameter of cell and nucleus are equal to $71.28 \pm 4.39 \mu \mathrm{m}$ and $25.08 \pm 0.03 \mu \mathrm{m}$, respectively. Middle stage (Cv2)
(Figure 1e): there is a thickening of the cell lining and the cytoplasmic vesicle become more abundant in the region adjacent to the nucleus. The cytoplasm is more proteic than that of the last stage. Diameters of cell and nucleus are $88.24 \pm 12.54 \mu \mathrm{m}$ and $25.28 \pm 4.49 \mu \mathrm{m}$, respectively. Final stage (Cv3) (Figure 1f): in this more advanced stage, 
the cytoplasmic vesicle occurs throughout the cytoplasm, which has an acidophilus character. Diameters of cell and nucleus are $146.52 \pm 26.07 \mu \mathrm{m}$ and $41.38 \pm 8.94 \mu \mathrm{m}$, respectively.

Vitellogenic oocytes (Vo) (Figure 1g): the cytoplasm is completely filled with vesicles, and protein granules occupy the cytoplasm periphery. Diameters of cell and nucleus are $223.44 \pm 33.50 \mu \mathrm{m}$ and $53.63 \pm 8.11 \mu \mathrm{m}$, respectively.

Mature oocytes (Mo) (Figure 1h): there is an increase in protein synthesis, resulting in increased number and size of the granules that fill the whole cytoplasm. In this phase the follicular epithelium is very thick. Diameters of cell and nucleus are, respectively, $435.30 \pm 11.84 \mu \mathrm{m}$ and $105.74 \pm 7.79 \mu \mathrm{m}$.

Hydrated oocytes (Ho) (Figure 1i): moments before being extruded, oocytes are hydrated, increasing in volume, with an average diameter of $604.91 \pm 101.29 \mu \mathrm{m}$. It is not possible to measure the diameter of nucleus due to its indefinite contours.

Atretic oocytes (Ao) (Figure 1j): mature oocytes that were not released become atretic and are probably absorbed by the gonads. They do not have a definite shape and appear strongly acidophilic and proteic.

Male cells were classified as spermatogonia, spermatocytes, spermatids and spermatozoa, as follows:

Spermatogonia (Sg) (Figure 2a): The largest cells of the male germ line, with $4.35 \pm 0.46 \mu \mathrm{m}$. A little protein and a basophilic reaction are present in the peripheral layer of the testicular acini.

Spermatocytes $(\mathbf{S c})$ (Figures 2a, b): cells are smaller than the spermatogonia, with $2.49 \pm 0.15 \mu \mathrm{m}$, showing a basophilic character. They are located in the peripheral layer of the testicular acini, concomitantly or not with other cells.

Spermatids (Sp) (Figures 2a, b): with a smaller diameter than spermatocytes $(2.03 \pm 0.31 \mathrm{~mm})$, the spermatids show a faintly acidophilic reaction and enhance the proteic nature, being found generally in the testicular acini, along with cells in other degrees of development.

Spermatozoa (Sz) (Figure 2b): they are the smallest germ cells, presenting the acrosome. They have $1.52 \pm 0.20 \mu \mathrm{m}$ in diameter and fill the testicular acini, being also occasionally present in the central lumen of the testis.

There were no differences in maturation between the anterior, middle and posterior regions of the gonads. Based on macroscopic characteristics of the gonads, such as length, width, weight (Table 1), colour, vascularity, texture, and size, as well as on the microscopic characteristics, such as histological organization and cellular composition, the following stages of sexual maturation were determined:

Immature female: Gonads have a reduced diameter and a translucent colour. The macroscopic sex identification is not possible. The coating is thin and ovigerous lamellae organized. Only Oo and Po are observed, with the eventual occurrence of $\mathrm{Cv}$ (Figure 3a). Ovaries with $\mathrm{Cv}$ absent were not observed, even in smaller individuals with rudimentary gonads. Although the presence of $\mathrm{Cv}$ indicates the beginning of maturation, due to organisation of lamellae and absence of indication of previous spawning, these specimens were considered immature.
Maturing Females/ Initial Stage: gonads are yellow in colour and show a slight increase in volume. At this stage, the length is presented statistically higher than in the immature stage. Pre vitellogenic oocytes are abundant, together with fewer cytoplasmic vesicle oocytes.

Maturing Females/ Final Stage: gonad colour varies between yellow and orange. In some specimens, the vascularization in gonad coating is evident. Several cytoplasmic vesicle oocytes and vitellogenic oocytes appear (Figure 3b).

Ripe Females: Gonads show a large increase in width and weight, higher than other stages $(p<0.05)$. The gonad is orange in colour and a highly vascularized coating. Mature oocytes are predominant, although oogonia, previtellogenic oocytes, cytoplasmic vesicle oocytes and vitellogenic oocytes are also present (Figure 3c). At an advanced stage, hydrated oocytes are also found (Figure $3 \mathrm{~d}$ ).

Partially-spawning females: This stage is macroscopically equal to spawning stage, orange in colour and a flaccid texture. The ovaries had partially spawned with the batch of Ho having already been released. In these cases, the ovary's characteristics were similar to the maturing or mature stages, except for the presence of residual cytoplasmic vesicles and some post ovulatory follicles (Figure 3e).

Spawning Females: ovaries orange in colour and a flaccid texture. Po and few Mo are observed, some with evidence of atresia. Several empty spaces, post ovulatory follicles and residual cytoplasmic vesicles remain in places where there used to be mature oocytes. The weight is again statistically equal to those of the immature and maturation stages, differing from the mature stage.

Resting females: Although macroscopically similar to the immature stage, the colour can vary from translucent to yellow. Microscopically, the gonadal lining appears thicker than in immature gonads. Oo, Po and follicle cells are observed in large numbers and in different regions. Unlike immature ovaries, ovigerous lamellae are not easily identified (Figure 3f).

Immature males: macroscopically similar to females; gonads have a reduced diameter and a translucent colour and the macroscopic sex identification is not possible. The testis presents a thin coating and underdeveloped acini. It is not possible to view the lumen, with only $\mathrm{Sg}$ and $\mathrm{Sc}$, although not numerous, being present at the periphery of the testis (Figure 2d)

Maturing Males: gonads exhibit a whitish colour and a lateral flattening, although its size and volume are still reduced. Spermatocytes, which occupy the peripheral acini with $\mathrm{Sp}$ (germinative zone) (Figure 2e), begin to proliferate. In the more central acini (maturation zone), a few sperms are already found. The lumen (Figure 2c) is filled with a non-cellular matrix and contains no sperm.

Ripe Males: testes are laterally flattened and rather bulky, being heavier than in other stages $(p<0.05)$. Acini of the peripheral region are filled with $\mathrm{Sg}, \mathrm{Sc}$ and $\mathrm{Sp}$. More central acini and the lumen are densely filled with $\mathrm{Sz}$ (Figure 2f).

Spent Males: testes are white, with a flaccid texture. Testicular lobes are fairly developed. Acini of the germinal zone are still filled by $\mathrm{Sp}$ and $\mathrm{Sc}$, whereas the maturation 

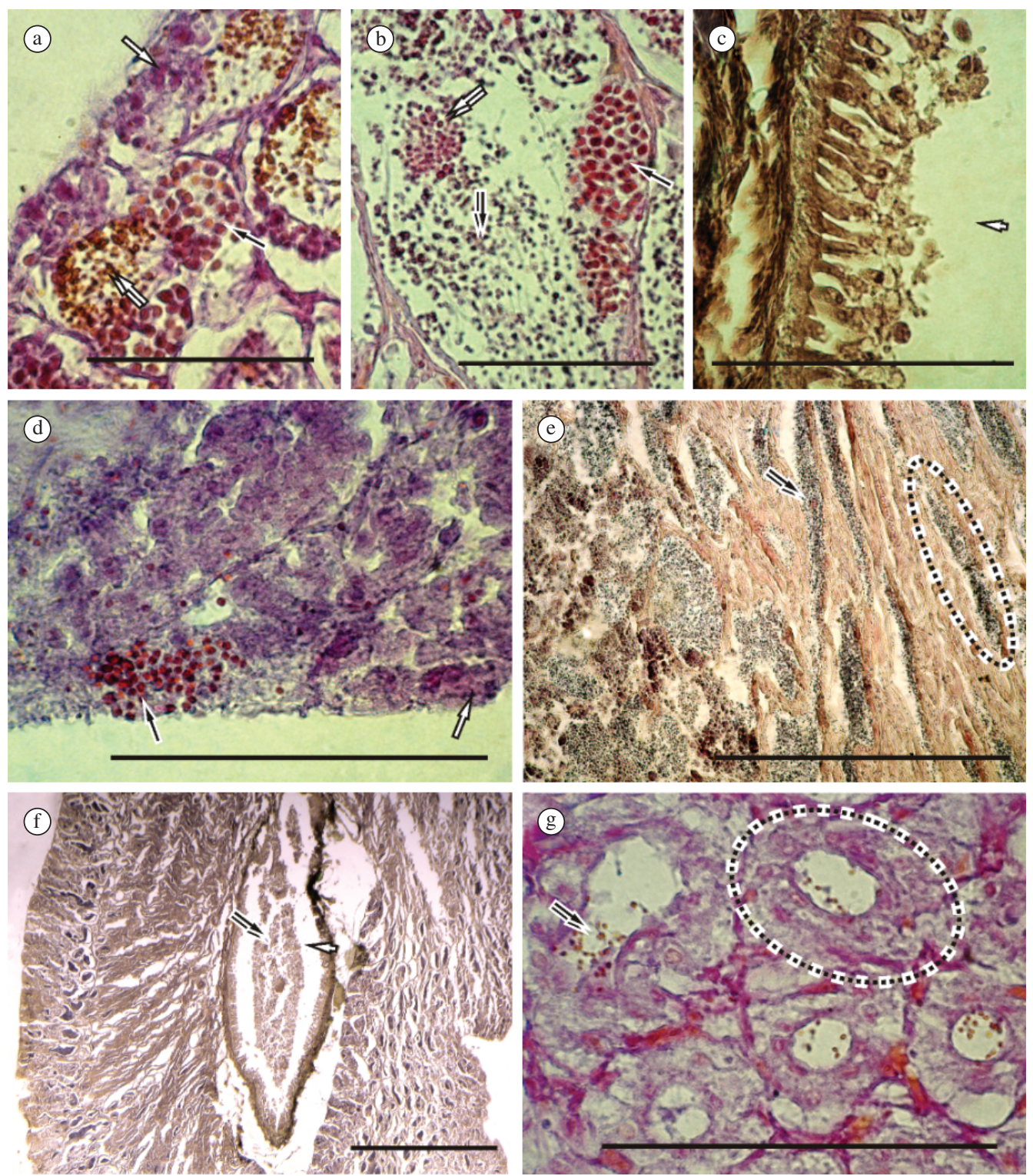

Figure 2. Photomicrographs of germ cell and testes development stages of H. plumieri. a, b) testicular acini containing spermatogonia (white arrow), spermatocytes (black arrow); spermatid (double white arrow) and spermatozoa (double black arrow); c) lumen of the testicle (short white arrow); d) Cross section of immature testis containing spermatogonia (white arrow) and spermatocytes (black arrow); e) Longitudinal section of maturing testis showing testicular acini (circle) fully of spermatozoa (double black arrow); f) Cross section of mature testis showing the peripheral region filled with germinative cells and the more central acini and the lumen (short white arrow) are densely filled with spermatozoa (double black arrow); g) Cross section of spent testis showing acini (circle) of the maturation zone with few residual sperm (double black arrow). Staining: Gomori's Trichrome (c, e, f) and Alcian blue/PAS (a, b, d, g). Scale bar: $50 \mu \mathrm{m}$ (a, b), $100 \mu \mathrm{m}$ (c, d, e, g) and $500 \mu \mathrm{m}$ (f).

zone and lumen are empty or with few sperms, only residual (Figure 2g).

Gonads of immature females and those of resting ones showed no significant difference for any of the measures, as well as in the macroscopic characteristics already described (Table 1) so that the differentiation between them is only possible with microscopic analysis.
In females, gonad growth in size and weight was observed from the immature to mature stage with them decreasing after spawning. For males, however, this tendency was not observed; it was observed an increase in testicle size from the immature to the spent stage (Table 1), while its weight increases until it reaches maturity, and decreases after emptying. 
Table 1. Length $\left(\mathrm{L}_{\mathrm{G}}\right)$, width $\left(\mathrm{S}_{\mathrm{G}}\right)$ and gonad weight $\left(\mathrm{W}_{\mathrm{G}}\right)( \pm$ standard derivation) in stages of gonadal maturation and $p$-value of non parametric ANOVA analysis. Different letters between the medians present significant differences using the KruskalWallis test $(p<0.05)$. Lengths, widths and weights as well as sexes were analysed separately.

\begin{tabular}{|c|c|c|c|}
\hline Female & $L_{G}$ & $S_{G}$ & $\mathbf{W}_{G}$ \\
\hline Immature & $2.78 \pm 0.19^{\mathrm{a}}$ & $0.41 \pm 0.01^{\mathrm{a}}$ & $0.27 \pm 0.01^{\mathrm{a}}$ \\
\hline Maturing-initial & $4.20 \pm 0.39^{\mathrm{bc}}$ & $0.68 \pm 0.02^{\mathrm{ab}}$ & $1.16 \pm 0.25^{\mathrm{ab}}$ \\
\hline Maturing-final & $4.70 \pm 0.39^{\mathrm{bc}}$ & $1.02 \pm 0.04^{\mathrm{bc}}$ & $2.69 \pm 0.79^{\mathrm{b}}$ \\
\hline Ripe & $5.28 \pm 0.56^{\mathrm{c}}$ & $1.16 \pm 0.06^{\mathrm{c}}$ & $5.12 \pm 5.52^{c}$ \\
\hline Spawning (total or partial) & $4.65 \pm 0.55^{\mathrm{abc}}$ & $0.58 \pm 0.02^{\mathrm{ab}}$ & $0.82 \pm 0.17^{\mathrm{ab}}$ \\
\hline Resting & $3.84 \pm 0.34^{\mathrm{ab}}$ & $0.58 \pm 0.01^{\mathrm{a}}$ & $0.56 \pm 0.09^{\mathrm{a}}$ \\
\hline$p$-value & $<0.0001$ & $<0.0001$ & $<0.0001$ \\
\hline \multicolumn{4}{|l|}{ Male } \\
\hline Immature & $3.81 \pm 0.55^{\mathrm{a}}$ & $0.29 \pm 0.05^{\mathrm{a}}$ & $0.49 \pm 0.10^{\mathrm{a}}$ \\
\hline Maturing & $3.93 \pm 0.64^{\mathrm{ab}}$ & $0.38 \pm 0.10^{\mathrm{a}}$ & $0.49 \pm 0.23^{\mathrm{ab}}$ \\
\hline Ripe & $4.89 \pm 0.54^{\mathrm{b}}$ & $0.44 \pm 0.17^{\mathrm{ab}}$ & $0.68 \pm 0.26^{c}$ \\
\hline Spent & $4.87 \pm 0.44^{\mathrm{b}}$ & $0.61 \pm 0.12^{\mathrm{b}}$ & $0.48 \pm 0.16^{\mathrm{b}}$ \\
\hline$p$-value & 0.0007 & 0.0046 & $<0.0001$ \\
\hline
\end{tabular}

\subsection{Spawning type}

Diameter classes displacement of oocytes during the maturation process (Figure 4), coupled with histological analysis, indicates that the species in northeastern region of Brazil presents a parceled spawning, of a synchronously type in more than two groups by presenting more than two batches of oocytes that increase synchronously in diameter up to spawning stage.

\section{Discussion}

The arrangement of the gonads in the abdominal cavity of individuals of $H$. plumieri was similar to that of several species of fish, including hermaphroditic species, e.g. Alphestes afer (Marques and Ferreira, 2011) or freshwater, e.g. Acestrorhynchus pantaneiro (Rodrigues et al., 2005). Due to the similarity between species of different families and orders, this feature seems to be intrinsic to the class Actinopterygii.

The distinction of sex based on the macroscopic characteristics of the gonads developed is evident, as also reported by Palazón-Fernandes (2007). However, for individuals with rudimentary gonads, this classification is not possible due to their similarity. This feature confirms the need to always examine the gonads microscopically to avoid errors.

Alves and Aragão (1973) and Palazón-Fernandez (2007) listed values of diameters of $H$. plumieri germ cells close to values found in this work, except for oogonia values of Alves and Aragão (1973) which are close to those of initial pre-vitellogenic oocyte (Po1). In this case, it is possible that such difference arises from different cell classifications and nomenclature used.

In most species of fish in which histological analyses were carried out, it was observed that in the ovaries of immature individuals there are only pre-vitellogenic cells (Shinozaki-Mendes et al., 2007). However, for $H$. plumieri, where it was observed cells in vitellogenesis even in the smallest individuals, only females in resting stage showed this pattern. Among the works that have carried out histological analysis of this species, PalazónFernandez (2007) did not show figures of an immature ovary (only the cells) and Alves and Aragão (1973) in their analysis, grouped immature and resting individual. Thus, we considered the hypothesis of the species directing energy for vitellogenesis early on. Another possibility is that the individuals classified as "immature" are actually in the initial maturation stage. In this case, the value of first maturation must be revised, although individuals classified as "immature" not have the characteristics of previous spawning.

Alves and Aragão (1973) report that H. plumieri males had total emptying due to the complete deflation of testis, corroborating with the current work, where developed testes were observed only with waste of sperm. PalazónFernandez (2007) concluded that this species had multiple spawning suggesting an asynchronous spawning, based only on oocytes variation into mature ovaries. If spawning was of an asynchronous type, spawned or at rest stages would be nonexistent, since mature oocytes are constantly being produced after the first maturity (Vazzoler, 1996). Silva and Murphy (2001) report that $H$. plumieri spawns once a year in Florida, with the peak in May. Whereas hydrated oocytes were observed in conjunction with the presence of mature oocytes, authors postulated that the species has a parceled spawning. In addition, Coward and Bromage (1998) cite that the presence of pre-vitellogenic oocytes in all maturational stages indicates that specimens are always available to restart the reproductive cycle.

For species with parceled spawning, we observed the same microscopic stages of development. A noticeable change is only related to nomenclature. Shinozaki-Mendes et al. 

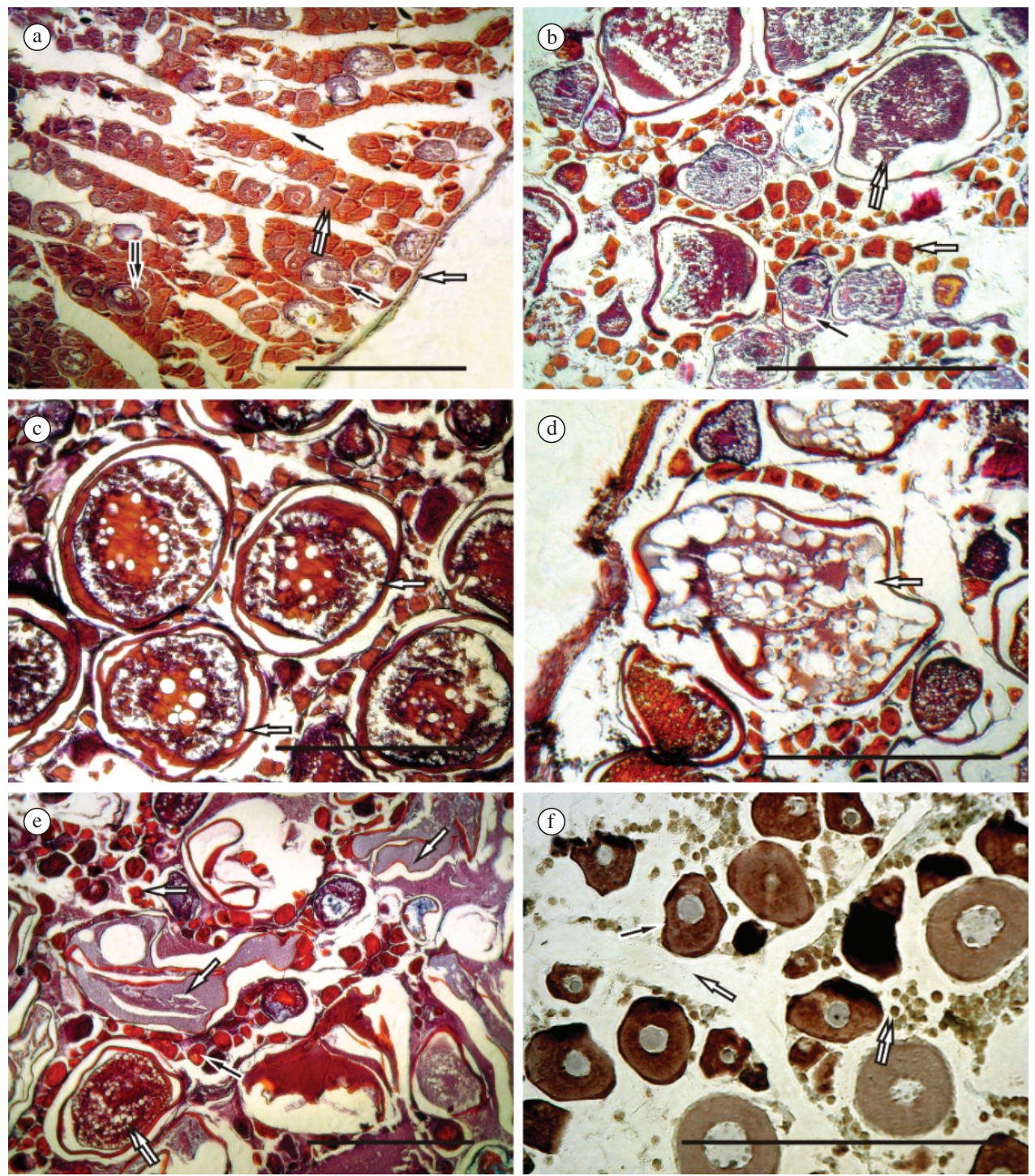

Figure 3. Photomicrographs of ovarian development stages of $H$. plumieri. a) Immature stage, showing thin coating (white arrow), ovigerous lamellae organised (black arrow), pre-vitellogenic oocytes (double white arrow) and cytoplasmic vesicle oocytes (double black arrow); b) Maturing stage, showing pre-vitellogenic oocytes (white arrow) and several cytoplasmic vesicle oocytes (black arrow) and vitellogenic oocytes (double white arrow); c) Ripe stage, with predominantly mature oocytes (white arrow); d) Ripe stage with hydrated oocytes (white arrow); e) Partially spawning, filled with liquefied cytoplasmic (white arrow), pre-vitellogenic oocytes (black arrow) and vitellogenic oocytes (double white arrow); f) Resting stage, showing ovigerous lamellae not easily identified (white arrow), pre-vitellogenic oocytes (black arrow) and many follicle cells (double white arrow). Staining: Alcian Blue/PAS (a, b, d, e), Hematoxylin-Eosin (c) and Gomori's Trichrome (f). Scale bar: $500 \mu \mathrm{m}$ (a, b, c, d), $250 \mu \mathrm{m}$ (e) and $150 \mu \mathrm{m}$ (f).

(2007) studying Holocentrus adscensionis, Chong and Gonzáles (2009) studying Genypterus chilensis e Cortés and Aron (2011) studying Isacia conceptionis found the same pattern described here for $H$. plumieri.

The parceled spawning is characteristic of most teleosts in the middle latitudes (Cortés and Aron, 2011) since individuals reproduce most of the year, unlike species in temperate waters, where there is a notorious seasonal variation (Vazzoler, 1996) and it is common to have a single spawning season and the reproductive period is well marked, e.g. Trachinotus marginatus (Lemos et al., 2011).

Thus, we can conclude that the ovarian development of $H$. plumieri occurs cyclically, in which the female can spawn more than two times during the season, with the spawning being "synchronous in more than two groups". Since males do not present the "rest" stage after copulation, the maturation process is continuous. 


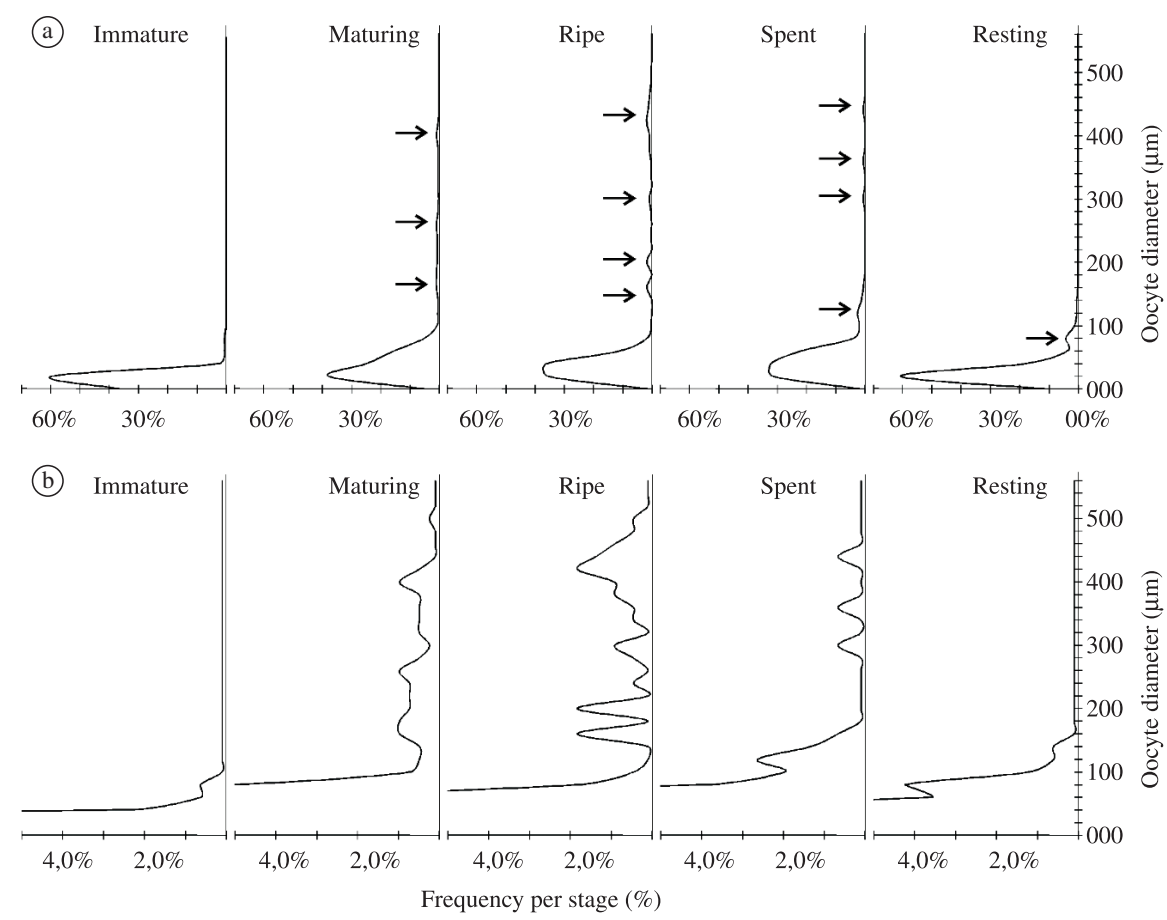

Figure 4. Frequency distribution of oocytes diameter in the five stages of ovarian maturation of $H$. plumieri, caught on the Ceara coast between January 2006 and August 2007. a) visualisation of all cell groups. Arrows indicate the batches of oocytes. b) close-up view of the frequency of up to $5 \%$. The values of oocyte diameter indicate the initial size of the class.

\section{References}

ALVES, MIM. and ARAGÃO, LP., 1973. Maturação sexual da biquara, Haemulon plumieri Lacépède (Pisces: Pomadasyidae). Arquivos de Ciências do Mar, vol. 13, no. 2, p. 69-76.

CHONG, J. and GONZÁLEZ, P. 2009. Ciclo reproductivo y talla media de madurez del congrio colorado, Genypterus chilensis (Guichenot, 1881) en el litoral de Talcahuano, Chile. Revista de Biología Marina y Oceanografía, vol. 44, p. 257-262. http:// dx.doi.org/10.4067/S0718-19572009000100027

CORTÉS, N. and ARON, A. 2011. Reproductive cycle and batch fecundity of Isacia conceptionis (Perciformes, Haemulidae) at La Herradura, Coquimbo, Chile. Revista de Biología Marina y Oceanografía, vol. 46, p.101-104. http://dx.doi.org/10.4067/ S0718-19572011000100016

COWARD, K. and BROMAGE, NR., 1998. Histological classification of oocyte growth and the dynamics of ovarian recrudescence in Tilapia zilii. Journal of Fish Biology, vol. 53, no. 2 , p. 285-302.

GARCIA-JÚNIOR, J., MENDES, LF., SAMPAIO, CLS. and LINS, JE., 2010. Biodiversidade marinha da bacia potiguar: ictiofauna. Rio de Janeiro: Museu Nacional. 195 p.

JUNQUEIRA, LC. and JUNQUEIRA, LMMS., 1983. Técnicas básicas de citologia e histologia. São Paulo: Livraria e Editora Santos. 123 p.

LEMOS, VM., VARELA JÚNIOR, AS., VELASCO, G. and VIEIRA, JP., 2011. The reproductive biology of the plata pompano, Trachinotus marginatus (Teleostei: Carangidae), in southern Brazil. Zoologia, vol 28, p. 603-609. http://dx.doi.org/10.1590/ S1984-46702011000500008

MARQUES, S. and FERREIRA, BP., 2011. Sexual development and reproductive pattern of the Mutton hamlet, Alphestes afer
(Teleostei: Epinephelidae): a dyandric, hermaphroditic reef fish. Neotropical Ichthyology, vol. 9, p. 547-558. http://dx.doi. org/10.1590/S1679-62252011005000026

MARZA, VD., 1938. Histophysiologie de l'Ovogenèse. Paris: Herman et Cie. $81 \mathrm{p}$.

MENDES, PP., 1999. Estatística aplicada à Aqüicultura. Recife: Ed. Bargaço. 265 p.

PALAZÓN-FERNÁNDEZ, J., 2007. Reproduction of the white grunt, Haemulon plumieri (Lacépede, 1802) (Pisces: Haemulidae) from Margarita Island, Venezuela. Scientia Marina, vol. 71, no. 3, p. 429-440. http://dx.doi.org/10.3989/scimar.2007.71n3429

RODRIGUES, LP., QUEROL, E. and BRACCINI, MC. 2005. Sescrição morfo-histológica do ovário de Acestrorhynchus pantaneiro (Menezes, 1992) (Teleostei, Characidae), em seus diferentes estádios de desenvolvimento, na Bacia do Rio Uruguai Médio, Uruguaiana, RS. Biodiversidade Pampeana, vol. 3, p. 11-18.

SHINOZAKI-MENDES, RA., HAZIN, FHV., OLIVEIRA, PG. and CARVALHO, FC., 2007. Reproductive biology of the squirrelfish, Holocentrus adscensionis (Osbeck, 1765), caught off the coast of Pernambuco, Brazil. Scientia Marina, vol. 71, no. 4, p. 715-722.

SILVA, JA. and MURPHY, MD., 2001. A Summary of the Status of White Grunt Haemulon plumieri from the East Coast of Florida. Florida Marine Research Institute. 18 p.

TOLOSA, EMC., RODRIGUES, CJ., BEHEMER, OA. and FREITAS-NETO, AG., 2003. Manual de técnicas histológica normal e patológica. Ed. Manole. $331 \mathrm{p}$.

VAZZOLER, AEAM., 1996. Biologia da reprodução de peixes teleósteos: teoria e pratica. Maringá: EDUEM. 96 p.

ZAR, JH., 1984. Biostatistical Analysis. Englewood Cliffs: Prentice Hall. 620 p. 